Check for updates

Cite this: RSC Adv., 2018, 8, 11705

\title{
Effect of alkali and alkaline earth metal species on the combustion characteristics of cattle manures
}

\author{
Baojun Yi, (D)*ab Qiaoxia Yuan, ${ }^{\text {ab }}$ Hongliang Cao, ${ }^{\text {ab }}$ Wenjuan Niu, ab Ming Wang, ${ }^{\text {ab }}$ \\ Yao Zhu ${ }^{a}$ and Shuiping Yan ${ }^{\text {ab }}$
}

This study investigates the effects of alkali and alkaline earth metal (AAEM) species on the combustion characteristics of cattle manures (CM). Different AAEM species ( $\mathrm{K}, \mathrm{Na}, \mathrm{Ca}$, and $\mathrm{Mg}$ ) were mixed with $\mathrm{CM}$ and deashing CM (D-CM) samples. The combustion characteristics of raw and char samples were compared. The effects of AAEM species on CM char were analyzed based on the structural characteristics of the char sample. Results show that $K$ and $\mathrm{Na}$ exert a positive effect, and this effect varies depending on the addition amount. $\mathrm{Ca}$ and $\mathrm{Mg}$ also exhibit a positive effect, but this effect does not change with the addition amount. The positive effect of $\mathrm{K}, \mathrm{Na}$, and $\mathrm{Ca}$ is related to the decrease in graphitization degree and increase in specific surface area. However, the positive effect of $\mathrm{Mg}$ is negligible. In conclusion, $\mathrm{CM}$ can be mixed with fuels containing $\mathrm{K}$ or $\mathrm{Na}$ in an appropriate ratio. The amount of $\mathrm{Ca}$ to be mixed with fuels has no specific requirement, whereas that of $\mathrm{Mg}$ to be mixed with fuels should be controlled

Received 31st January 2018

Accepted 13th March 2018

rsc.li/rsc-advances gasification and the high content of potassium in the ash limit the application of livestock and poultry manure gasification. ${ }^{2}$ By contrast, burning of poultry manures has attracted widespread attention as a direct and complete process to generate energy. ${ }^{\mathbf{1 4}}$ At present, combustion of livestock and poultry manures is performed through co-firing or direct combustion. Co-firing is easier to achieve than direct combustion, ${ }^{15,16}$ but it needs a suitable coal-fired power plant surrounding. Compared with co-firing, direct combustion has less requirements and impact on the surrounding environment. Thus, direct combustion is the better choice to treat livestock and poultry manures for large-scale farms.

Most livestock and poultry manures in China are abundant in $\mathrm{K}, \mathrm{Ca}$, and $\mathrm{Mg} .{ }^{17}$ Previous studies confirmed that $\mathrm{K}, \mathrm{Na}, \mathrm{Ca}$, and $\mathrm{Mg}$ in low-rank fuels catalyze gasification ${ }^{18-22}$ and combustion. $^{23,24} \mathrm{Hu}$ et al. studied the catalytic effects of inherent alkali and alkaline earth metals (AAEMs) on pyrolysis and gasification of biomass. ${ }^{25,26}$ Cheng et al. ranked the catalytic effect of AAEMs on the combustion of pulverized coal to be $\mathrm{Na}>$ $\mathrm{Fe}>\mathrm{Ca}>\mathrm{Al}^{.23}$ However, excessive AAEMs can lead to severe fouling and slagging. ${ }^{27,28}$ A suitable proportion of $\mathrm{CaO}$ can significantly reduce the alkali metal content of chars and slagging. ${ }^{29,30}$ As a disadvantage of AAEM on the combustion of agriculture, forestry, and straw biomass, washed biomass can induce deashing to promote combustion. ${ }^{31}$ For livestock and poultry manures, washing needs huge amounts of water and cause secondary pollution due to the large number of organic matter and pathogens. Meanwhile, pickling is of high cost. Therefore, understanding the effects of AAEM species on the burning of livestock and poultry manures is important.
${ }^{a}$ College of Engineering, Huazhong Agricultural University, No. 1, Shizishan Street, Hongshan District, Wuhan, 430070, P. R. China.E-mail: bjyi@mail.hzau.edu.cn; Fax: +8627 87282120; Tel: +862787282120

${ }^{b}$ Key Laboratory of Agricultural Equipment in the Mid-lower Yangtze River, Ministry of Agriculture, Wuhan, 430070, P. R. China 
Most previous studies focused on the effects of inherent AAEM species on the pyrolysis and combustion of biomass. ${ }^{25,26}$ Few studies investigated the impact of external AAEM content on livestock and poultry manures after deashing. In the actual transfer process, external ash is easily to be mixed to livestock and poultry manure. Furthermore, whether the addition of external ash would facilitate combustion reaction need further research. In the present study, typical cattle manure (CM) was selected as the object of research, and the effect of AAEM species ( $\mathrm{K}, \mathrm{Na}, \mathrm{Ca}$, and $\mathrm{Mg}$ ) on the combustion of $\mathrm{CM}$ was discussed.

\section{Experimental}

\subsection{Materials and pretreatment}

All CM samples used in the experiment were freshly collected from a dairy farm of Dongzheng Livestock and Poultry Co., Ltd. in Jiangxia District, Wuhan, Hubei Province. CM was dehydrated in air at the College of Engineering Laboratory of Huazhong Agricultural University. CM was dried in a drying oven at $105{ }^{\circ} \mathrm{C}$ for $48 \mathrm{~h}$ before the experiment. Then, dried CM was crushed into powder and passed through a 60-mesh sieve. Proximate analysis, ultimate analysis, low heating value, chemical composition, and inorganic substances are shown in Table 1 . The proportion of volatile matter was $45.80 \%$ on the dry basis of CM, and the proportions of ash and fixed carbon were $32.19 \%$ and $12.52 \%$, respectively. Volatile matter is the main body of combustible CM. Ultimate analysis revealed $\mathrm{O}$ content of $49.92 \%$ and $\mathrm{C}$ content of $41.13 \%$. High $\mathrm{O}$ and low $\mathrm{H}$ caused the small lower heating values, which is $13.426 \mathrm{MJ} \mathrm{Kg}^{-1}$. The main chemical composition of CM was $24.05 \%$ cellulose, $26.24 \%$ hemicellulose, and $5.16 \%$ lignin. The chemical composition in biomass is responsible for the different thermochemical properties. Lignin is the most difficult one to decompose among the three components. ${ }^{32}$ Hence, low content lignin in CM is expected to result in good combustion reactivity. The main inorganic substances of raw $\mathrm{CM}$ are $\mathrm{Si}, \mathrm{Ca}, \mathrm{K}, \mathrm{Al}$, and $\mathrm{Mg}$. Some AAEM species in CM is in favor of comparing the impact of internal and external AAEM species. To clarify the effect of external AAEM ( $\mathrm{K}, \mathrm{Na}, \mathrm{Ca}$, and $\mathrm{Mg}$ ) species on the combustion of $\mathrm{CM}, \mathrm{K}_{2} \mathrm{CO}_{3}, \mathrm{Na}_{2} \mathrm{CO}_{3}, \mathrm{CaCO}_{3}$, and $\mathrm{MgCO}_{3}$ were blended with the deashing samples. The alkali metal carbonate has a good catalytic effect. ${ }^{33,34}$ In addition, the product result from the decomposition reaction of carbonate may not affect the experiment. Deashing method was introduced everywhere. ${ }^{35,36}$ This process was carried out by mixing a $5 \mathrm{~g}$ CM sample with $100 \mathrm{~mL}$ of $50 \% \mathrm{HCl}$ and stirring for $2 \mathrm{~h}$ in a water bath at $75^{\circ} \mathrm{C}$. The sample was cooled, filtered, and then washed in distilled water for three times. The sample was then mixed with $100 \mathrm{~mL}$ of $50 \% \mathrm{HF}$, then the previous step was repeated. After three times of HCl-HF washing, the sample was dried and identified as D-CM. The experimental material was pretreated several times by the above deashing process to obtain enough DCM samples, which were placed in a sealed bag and stored in the freezer. Different contents of AAEM species were compared. The blend ratios were $2.5 \%, 5 \%$, and $7.5 \%$ in weight. The blending of CM/D-CM and AAEMs were immersed in water solution ( $1 \mathrm{~g}$ of solid sample per $10 \mathrm{~mL}$ agent), stirred for $2 \mathrm{~h}$ at ambient temperature $\left(25 \pm 3{ }^{\circ} \mathrm{C}\right)$, and then it dried at $55{ }^{\circ} \mathrm{C}$ in an oven for $24 \mathrm{~h}$. The dried samples were shaked for $10 \mathrm{~min}$.

Char was prepared in accordance with a previously described method to distinguish the effect of AAEM species on volatile matter and fixed carbon in CM. ${ }^{37}$ In the present study, we conducted $800{ }^{\circ} \mathrm{C}$ storage for $30 \mathrm{~min}$ under $\mathrm{N}_{2}$ atmosphere. The sample amount was $5 \mathrm{~g}$ each time, the blend ratio was 5\% AAEM species, and the gas flow rate was set to $1 \mathrm{~L} \mathrm{~min}^{-1}$. The char samples prepared from CM and deashing CM were named as CM char and D-CM char, respectively. The method of dissolving and re-drying was chosen to blend $\mathrm{K}_{2} \mathrm{CO}_{3}, \mathrm{Na}_{2} \mathrm{CO}_{3}, \mathrm{CaCO}_{3}$, and $\mathrm{MgCO}_{3}$ in the sample. ${ }^{38,39}$

Raw CM mixed with $\mathrm{K}_{2} \mathrm{CO}_{3}, \mathrm{Na}_{2} \mathrm{CO}_{3}, \mathrm{CaCO}_{3}$, and $\mathrm{MgCO}_{3}$ were denoted by $\mathrm{CM} \mathrm{K} \mathrm{KO}_{3}, \mathrm{CM} \mathrm{Na} \mathrm{CO}_{3}, \mathrm{CM} \mathrm{CaCO}_{3}$, and $\mathrm{CM}$ $\mathrm{MgCO}_{3}$, respectively. D-CM char mixed with $\mathrm{K}_{2} \mathrm{CO}_{3}, \mathrm{Na}_{2} \mathrm{CO}_{3}$, $\mathrm{CaCO}_{3}$, and $\mathrm{MgCO}_{3}$ were named as D-CM K $\mathrm{K}_{2} \mathrm{CO}_{3}$ char, D-CM $\mathrm{Na}_{2} \mathrm{CO}_{3}$ char, D-CM $\mathrm{CaCO}_{3}$ char, and D-CM $\mathrm{MgCO}_{3}$ char, respectively.

\subsection{Experimental methods}

Inductively coupled plasma optical emission spectrometry (Perkin Elmer Optima 8000DV) was performed to analyze inorganic species. Field emission-scanning electron microscopy (JEOL JSM-6390LV) was employed to observe the surface

Table 1 Proximate analysis, ultimate analysis, LHV, chemical structure and inorganic species of CM/D-CM

\begin{tabular}{|c|c|c|c|c|c|c|c|c|c|c|c|}
\hline \multirow[b]{2}{*}{ Sample } & \multicolumn{3}{|c|}{ Proximate analysis (wt\% daf) } & \multicolumn{5}{|c|}{ Ultimate analysis (wt\% daf) } & \multicolumn{3}{|c|}{ Chemical structure (wt $\%$ daf) } \\
\hline & $\mathrm{V}$ & $\mathrm{A}$ & FC & $\mathrm{C}$ & $\mathrm{H}$ & $\mathrm{O}^{a}$ & $\mathrm{~N}$ & S & Hemicellulose & Cellulose & Lignin \\
\hline D-CM & 65.73 & 7.06 & 27.21 & 44.27 & 6.21 & 46.77 & 2.46 & 0.29 & - & - & - \\
\hline
\end{tabular}

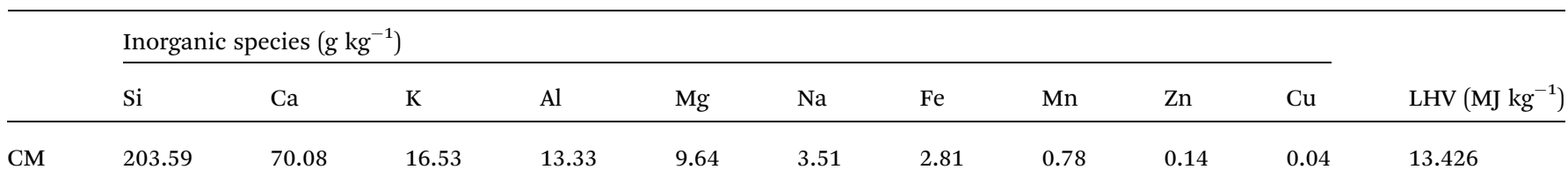


topography of the sample. BRUKER D8 ADVANCE was used to analyze carbon crystal structure and mineral crystal type at 40 $\mathrm{KV}$ working voltage and $40 \mathrm{~mA}$ tube current with $\mathrm{Cu}-\mathrm{K} \alpha$ radiation, respectively. The diffraction peak was collected by a stepby-step scanning method, and the order was $0.01^{\circ} .2 \theta$ in the range of $10-90^{\circ}$ was recorded in the diffraction data. Specific surface area and pore structure were analyzed using the Accelerated Surface Area and Porosimetry System (ASAP 2020) in accordance with a previously described method. ${ }^{40}$

Thermogravimetric analysis (TGA) has been widely used in the study of thermochemical conversion processes. ${ }^{\mathbf{4 1 - 4 4}}$ Combustion reactivity experiments were conducted in the simultaneous DSC-TGA Q600. First, $10 \pm 0.2 \mathrm{mg}$ of sample was placed in an alumina crucible. The thermal analysis program was heated to $800{ }^{\circ} \mathrm{C}$ from room temperature at $20{ }^{\circ} \mathrm{C} \mathrm{min}{ }^{-1}$. The furnace atmosphere was simulated air by mixing $21 \% \mathrm{O}_{2}$ and $79 \% \mathrm{~N}_{2}$. Total gas flow rate was $100 \mathrm{~mL} \mathrm{~min}^{-1}$.

\subsection{Combustion parameters}

Several main combustion characteristic temperatures were used for comparison among different atmospheres, including start weight loss temperature $\left(T_{\mathrm{s}}\right)$, ignition temperature $\left(T_{\mathrm{ig}}\right)$, temperature of the maximum combustion rate $\left(T_{\max }\right)$, and burnout temperature $\left(T_{\mathrm{b}}\right)$, which were obtained through thermal gravimetric curves in accordance with previously described methods. ${ }^{37,44}$

\section{Results and discussion}

\subsection{Combustion characteristics curve}

Livestock and poultry manure combustion presents a bimodal curve. One is the devolatilization stage $\left(200-390{ }^{\circ} \mathrm{C}\right)$, which represents the release of volatiles and ignition, whereas the other one $\left(400-600{ }^{\circ} \mathrm{C}\right)$ is related to char oxidation. ${ }^{45,46}$ Raw CM in our experiment was also divided into two stages, as depicted in Fig. 1. The first stage at $250-400{ }^{\circ} \mathrm{C}$ is for volatile matter release and combustion. The second stage at $420-550{ }^{\circ} \mathrm{C}$ is for char combustion. Meanwhile, the weight loss rates of the first and second peaks were about $41.06 \%$ and $20.56 \%$, respectively,

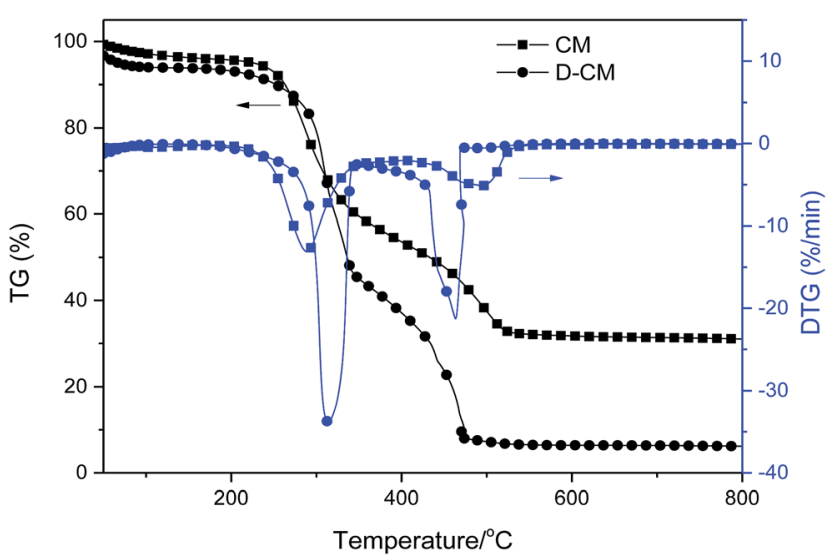

Fig. 1 Combustion curves of CM/D-CM in air atmosphere under nonisothermal condition. which are consistent with the contents of volatile matter and fixed carbon. This result indicates that CM at low-heating-rate combustion conditions features clear-phased combustion characteristics.

The ash ratio of D-CM was 6\%. As shown from the DTG diagram, the volatile mater of D-CM was released later than that of raw CM, indicating that some volatile matter were easily released or catalytic mineral was lost during deashing, which is in accordance with the literature. ${ }^{22}$ The peak of volatile matter and fixed carbon in D-CM is $49.09 \%$ and $36.84 \%$, respectively, which are increased with decreasing ash content and increasing combustible content. D-CM appeared at a low burnout temperature. A similar phenomenon with other materials was reported. ${ }^{47,48}$ The phenomenon may be caused by the intense burning of $\mathrm{D}$-CM in air atmosphere. As a result, the sample temperature was provisionally above the heating program's temperature. After a short time, the sample temperature returned to the program temperature, and the heating process continued.

As illustrated in Fig. 2a, the combustion curves moved to lower temperature as $\mathrm{K}_{2} \mathrm{CO}_{3}$ content was further increased. The volatile matter released and char combusted ahead of time, whereas $T_{\mathrm{b}}$ showed a decreasing trend. However, the rate of weight loss gradually decreased. As displayed in Fig. 2b, the combustion curves moved to a lower temperature with increasing $\mathrm{Na}_{2} \mathrm{CO}_{3}$. $\mathrm{K}$ and $\mathrm{Na}$ had lower reaction temperatures than the other AAEM species, indicating an improvement in reactivity. A decrease in weight loss corresponded to decreased combustible concentration with the addition of AAEM. As shown in Fig. 2c and d, only $7.5 \%$ of $\mathrm{CaCO}_{3}$ mixing was conducive to the release of volatile matter when the added contents of $\mathrm{CaCO}_{3}$ and $\mathrm{MgCO}_{3}$ were increased. Other contents played no significant role in promoting the release of volatile matter, but all the char burnout processes were improved. In conclusion, $\mathrm{K}$ and $\mathrm{Na}$ exerted a positive impact on the starting reaction temperature. The addition of $\mathrm{K}, \mathrm{Na}, \mathrm{Ca}$, and $\mathrm{Mg}$ improved burnout, but combustible concentration decreased with the addition of AAEM.

To study the effect of internal and external AAEM species on $\mathrm{CM}$ combustion, the combustion of $\mathrm{K}, \mathrm{Na}, \mathrm{Ca}$, and $\mathrm{Mg}$ blends in D-CM is shown in Fig. 3. $\mathrm{K}$ and $\mathrm{Na}$ showed similar trends. Compared with the curves of D-CM, the peaks of volatile matter release and char combustion of D-CM K $\mathrm{CO}_{3}$ and D-CM Na $\mathrm{CO}_{3}$ moved to a lower temperature. The blend with $2.5 \%$ content had a larger volatile matter release peak than the other blends. With the increase in amount, volatile matter release peak gradually decreased, and the decrease rate of D-CM Na${ }_{2} \mathrm{CO}_{3}$ was greater than that of D-CM K $\mathrm{CO}_{3}$. For D-CM K $\mathrm{CO}_{3}$, the starting point of char combustion peak with $2.5 \%$ mixing content coincided with the volatile matter release peak, and the end time of its weight loss peak significantly decreased. With the increase in $\mathrm{K}_{2} \mathrm{CO}_{3}$ blend amount in D-CM, the char combustion peak gradually moved to a higher temperature. However, 5\% mixing content for the lowest temperature of char combustion peak was observed for D-CM $\mathrm{Na}_{2} \mathrm{CO}_{3}$. As the amount of $\mathrm{Na}_{2} \mathrm{CO}_{3}$ blend increased, temperature of char combustion peak moved to a higher temperature. The temperature of char combustion 

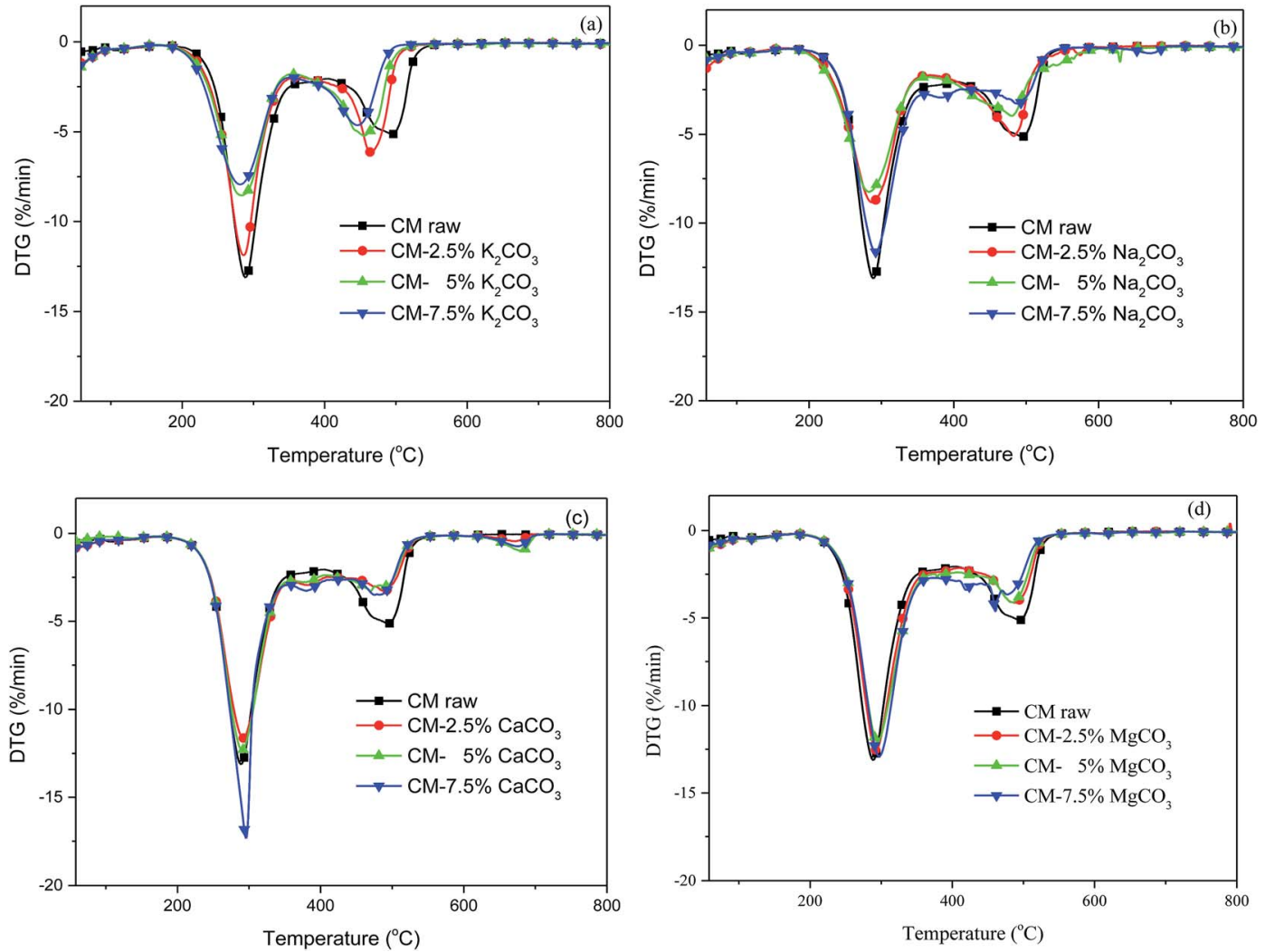

Fig. 2 Effect of mixed content with various AAEM species on the combustion curves of $\mathrm{CM}$. (a) $\mathrm{K}_{2} \mathrm{CO}_{3},(\mathrm{~b}) \mathrm{Na}_{2} \mathrm{CO}_{3}$, (c) $\mathrm{CaCO}_{3}$, (d) $\mathrm{MgCO}_{3}$.
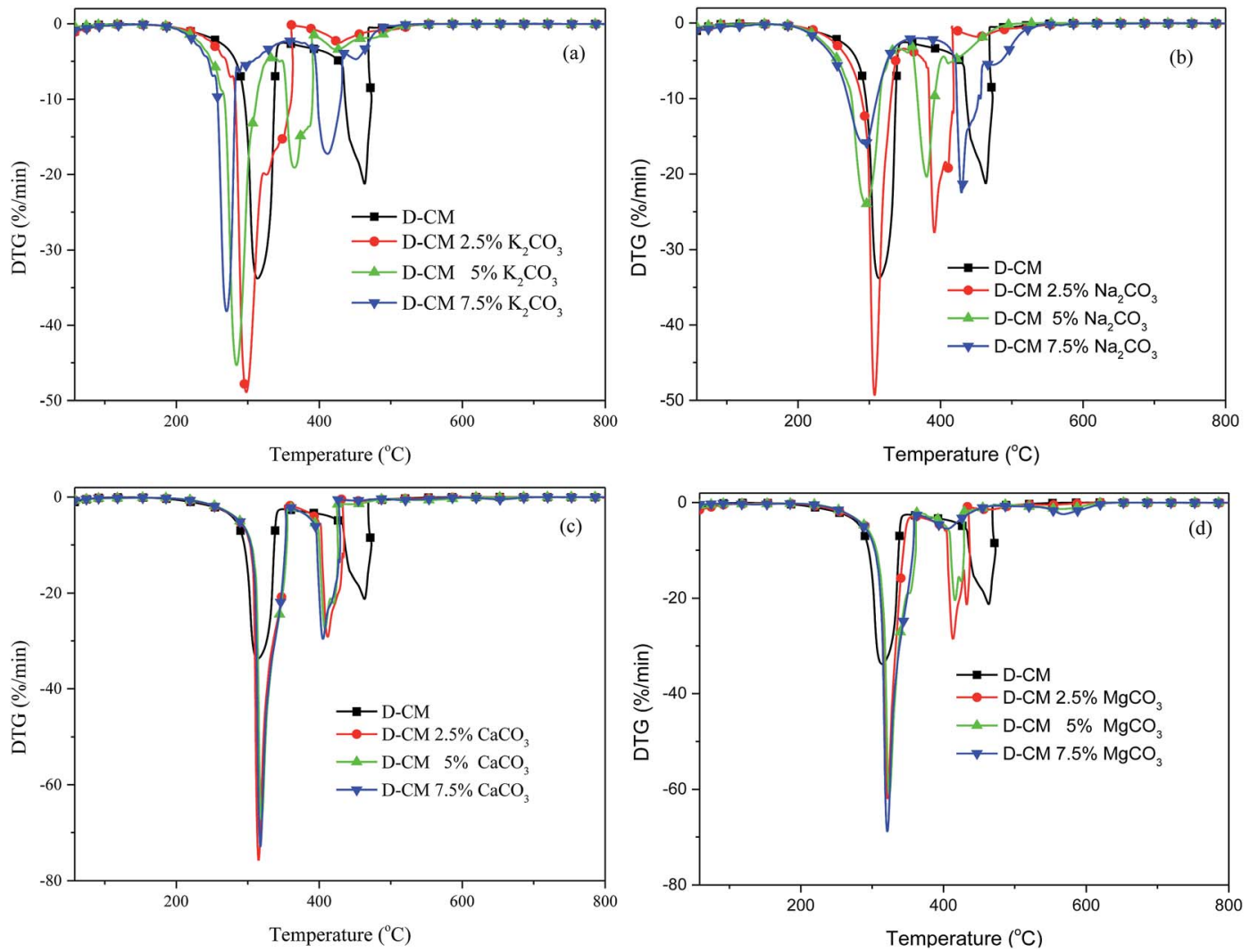

Fig. 3 Effect of mixed content with various AAEM species on the combustion curves of D-CM. (a) $\mathrm{K}_{2} \mathrm{CO}_{3}$, (b) $\mathrm{Na}_{2} \mathrm{CO}_{3}$, (c) $\mathrm{CaCO}_{3}$, (d) $\mathrm{MgCO}_{3}$. 

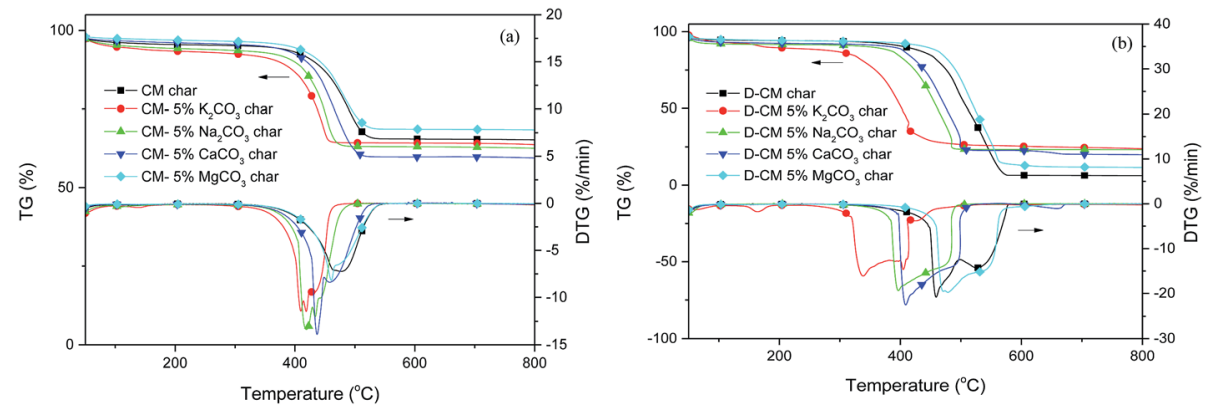

Fig. 4 Effect of AAEM species blended in CM or D-CM on the combustion characteristics of the char sample. (a) CM, (b) D-CM.

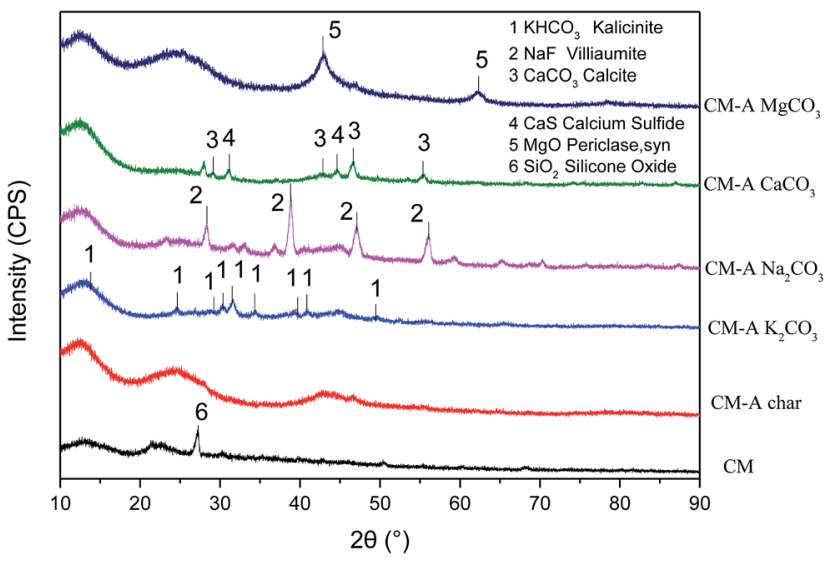

Fig. 5 XRD analysis of the char prepared under various AAEM species blended in D-CM.

peak of 7.5\% mixing content was also lower than that of D-CM. Fig. $3 \mathrm{c}$ and $\mathrm{d}$ show that $\mathrm{Ca}$ and $\mathrm{Mg}$ have similar trends. The peak height of the two weight losses increased, and the volatile matter release peak increased by nearly 1 time. However, $T_{\mathrm{s}}$ increased. The char combustion peak moved to a lower temperature. This effect was not influenced by the increase in mixing amount. In summary, external $\mathrm{K}, \mathrm{Na}, \mathrm{Ca}$, and $\mathrm{Mg}$ blends favored the combustion of volatile matter and char in D-CM. Promotion of $\mathrm{K}$ and Na decreased as the blend amount was increased within $2.5-7.5 \%$, but the promotion of $\mathrm{Ca}$ and $\mathrm{Mg}$ did not change with the increase in mixing amount. Combined with the conclusion in Fig. 2, internal and external $\mathrm{K}, \mathrm{Na}, \mathrm{Ca}$, and $\mathrm{Mg}$ in CM exert a catalytic effect on combustion.

To study the different effects of AAEM species on volatile matter and char reaction in $\mathrm{CM}$, the combustion characteristics of $5 \% \mathrm{~K}_{2} \mathrm{CO}_{3}, \mathrm{Na}_{2} \mathrm{CO}_{3}, \mathrm{CaCO}_{3}$, and $\mathrm{MgCO}_{3}$ blend $\mathrm{CM} / \mathrm{D}-\mathrm{CM}$ char were analyzed (Fig. 4). After blending the AAEM species in CM, $(\mathrm{d} w / \mathrm{d} t)_{\max }$ increased and $T_{\mathrm{s}}$ decreased, but the change in the $\mathrm{MgCO}_{3}$ blend was smaller than those in the other substances. $T_{\mathrm{s}}$ was in the order of $\mathrm{K}_{2} \mathrm{CO}_{3}>\mathrm{Na}_{2} \mathrm{CO}_{3}>\mathrm{CaCO}_{3}>\mathrm{MgCO}_{3}$, and $(\mathrm{d} w /$ $\mathrm{d} t)_{\max }$ was $\mathrm{CaCO}_{3}>\mathrm{Na}_{2} \mathrm{CO}_{3}>\mathrm{K}_{2} \mathrm{CO}_{3}>\mathrm{MgCO}_{3}$. The trend of $T_{\mathrm{b}}$ was the same as that of $T_{\mathrm{s}}$. In conclusion, only $\mathrm{Ca}, \mathrm{Na}$, and $\mathrm{K}$ significantly influenced the reactivity of CM char. Combining the result from the Fig. 2, the AAEM species catalyzed CM combustion. The improved reactivity of $\mathrm{K}_{2} \mathrm{CO}_{3}, \mathrm{Na}_{2} \mathrm{CO}_{3}$, and $\mathrm{CaCO}_{3}$ on $\mathrm{CM}$ combustion not only existed in the volatile matter release stage but also in the combustion stage of char.

As shown in Fig. $4 \mathrm{~b}$, the $T_{\mathrm{s}}$ and $T_{\mathrm{b}}$ of D-CM char significantly decreased after mixing with $\mathrm{Na}_{2} \mathrm{CO}_{3}, \mathrm{CaCO}_{3}$, and, especially, $\mathrm{K}_{2} \mathrm{CO}_{3}$. The characteristic temperature of the $\mathrm{K}_{2} \mathrm{CO}_{3}$ blend in DCM decreased up to $150{ }^{\circ} \mathrm{C}$. The $T_{\mathrm{s}}$ and $T_{\mathrm{b}}$ for mixing with $\mathrm{Na}_{2} \mathrm{CO}_{3}$ and $\mathrm{CaCO}_{3}$ in D-CM char decreased by more than $50^{\circ} \mathrm{C}$. After the $\mathrm{MgCO}_{3}$ blend, the $T_{\mathrm{S}}$ of D-CM increased by $20^{\circ} \mathrm{C}$, but its $T_{\mathrm{b}}$ did not have any change. Thus, promoting the effect of $\mathrm{K}$, $\mathrm{Na}$, and $\mathrm{Ca}$ on D-CM combustion is in the order $\mathrm{K}>\mathrm{Na}>\mathrm{Ca}$, and it is similar to AAEM species for CM char combustion.

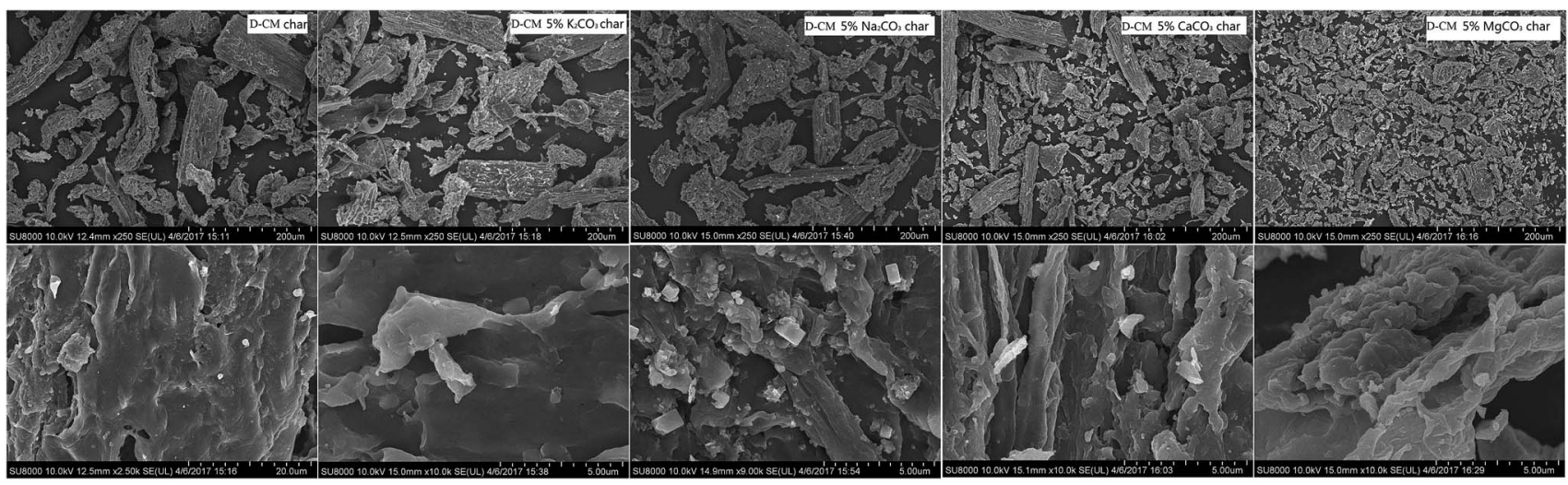

Fig. 6 SEM analysis of the char prepared under various AAEM species blended in D-CM. 

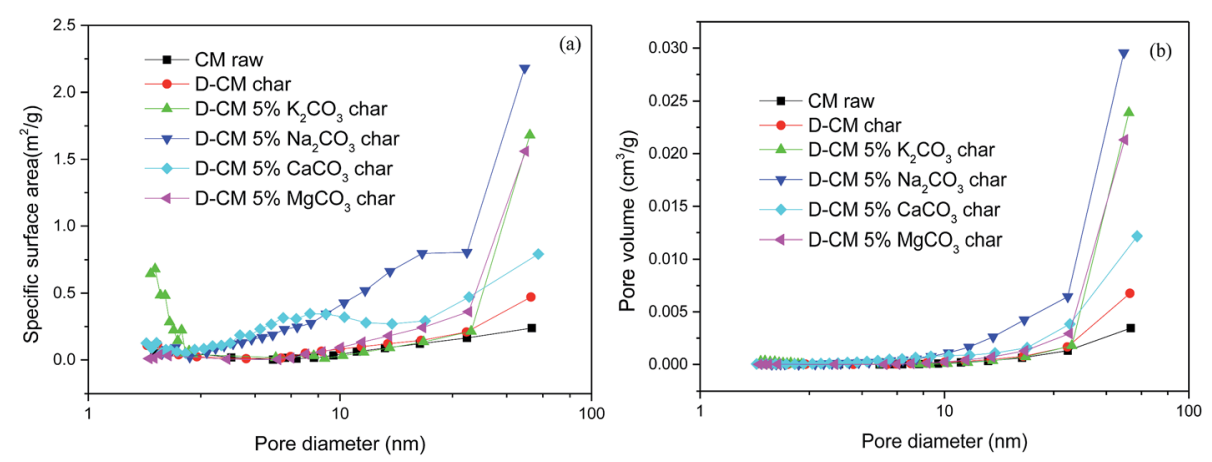

Fig. 7 Distribution characteristics of pore structure with pore size of the char prepared under various AAEM species blended in D-CM. (a) Specific surface area, (b) pore volume.

\subsection{Structural characterization}

The study above revealed that the blending of $\mathrm{K}_{2} \mathrm{CO}_{3}, \mathrm{Na}_{2} \mathrm{CO}_{3}$, $\mathrm{CaCO}_{3}$, and $\mathrm{MgCO}_{3}$ with D-CM significantly influenced the combustion characteristics, but whether this effect is related to the carbon crystal structure and mineral crystal structure has yet to be determined. To this end, the pyrolysis char were prepared by the blends of 5\% AAEM species and D-CM. XRD analysis is shown in Fig. $5 \mathrm{~d}_{002}$ and $\mathrm{d}_{10}$ peaks are related to the carbon crystal structure. ${ }^{49}$ Compared with raw CM, D-CM char had more obvious $\mathrm{d}_{002}$ and $\mathrm{d}_{10}$ peaks. D-CM $\mathrm{MgCO}_{3}$ char showed significant $\mathrm{d}_{002}$ and $\mathrm{d}_{10}$ peaks too. Both D-CM char and D-CM $\mathrm{MgCO}_{3}$ char demonstrated a high degree of graphitization, which affected the reactivity of the char. The D-CM char mixed with $\mathrm{K}_{2} \mathrm{CO}_{3}, \mathrm{Na}_{2} \mathrm{CO}_{3}$, and $\mathrm{CaCO}_{3}$ displayed no obvious $\mathrm{d}_{002}$ and $\mathrm{d}_{10}$ peaks. The degree of graphitization was low, and combustion reactivity was high. In summary, $\mathrm{K}_{2} \mathrm{CO}_{3}, \mathrm{Na}_{2} \mathrm{CO}_{3}$, and $\mathrm{CaCO}_{3}$ can improve the reactivity of $\mathrm{CM}$ char during pyrolysis and prevent the formation of a graphitization structure. However, $\mathrm{Mg}$ promoted the formation of graphitization by reducing the reactivity of char. From the blends of D-CM and AAEM species, the main minerals were $\mathrm{KHCO}_{3}, \mathrm{NaF}, \mathrm{CaCO}_{3}$, and $\mathrm{CaS}, \mathrm{MgO}$ in the D-CM $\mathrm{K}_{2} \mathrm{CO}_{3}$ char, D-CM Na $\mathrm{CO}_{3}$, D-CM $\mathrm{CaCO}_{3}$ char, and D-CM MgCO 3 char, respectively. This finding indicates that the AAEM species were converted to other substances during pyrolysis. Therefore, the promotion of $\mathrm{K}, \mathrm{Na}$, and $\mathrm{Ca}$ on the combustion of D-CM char are related to reducing graphitized structure while the enhanced graphitized structure of D-CM $\mathrm{MgCO}_{3}$ char leads to the low reactivity of $\mathrm{CM}$ with the addition of $\mathrm{MgCO}_{3}$. As is verified in the literature, ${ }^{50}$ through facilitating ion-exchangeable cations, AAEMs play an important role in the formation of light hydrocarbons, oxygen-containing species, char and tar, thus affecting release of volatile matter and formation of char. In addition to promoting breakage and restructuring of hetero atoms of tar, AAEMs also enhanced the thermal decomposition of heavier aromatics. ${ }^{26}$

$\mathrm{K}_{2} \mathrm{CO}_{3}, \mathrm{Na}_{2} \mathrm{CO}_{3}$, and $\mathrm{CaCO}_{3}$ promoted whereas $\mathrm{MgCO}_{3}$ inhibited the combustion reaction of AAEM species blended in D-CM char. To this end, SEM images of char were analyzed as shown in Fig. 6. The D-CM char displayed a large particle size and rich porosity. In the graph magnified $250 \times$, the char particle size after blending with $\mathrm{K}_{2} \mathrm{CO}_{3}$ and $\mathrm{Na}_{2} \mathrm{CO}_{3}$ remained large, but the average particle size of the blend $\mathrm{CaCO}_{3}$ and $\mathrm{MgCO}_{3}$ decreased. Magnification $10000 \times$ revealed many small particles attached to the surface of mixed $\mathrm{K}_{2} \mathrm{CO}_{3}, \mathrm{Na}_{2} \mathrm{CO}_{3}$, and $\mathrm{CaCO}_{3}$ particles, and these particles formed micro-pores. The surface of sample blended with $\mathrm{MgCO}_{3}$ was sintered into blocks and showed no obvious fine particle adhesion. Less reaction surface to contact with oxygen was available, which is one of the reasons leading to poor combustion characteristics.

Previous SEM images showed that D-CM chars mixed with $\mathrm{K}_{2} \mathrm{CO}_{3}, \mathrm{Na}_{2} \mathrm{CO}_{3}$, and $\mathrm{CaCO}_{3}$ have more fine particles, which form larger pore structures. The BET test was carried out to determine the effect of AAEM species on the pore structure of DCM char. Results are shown in Fig. 7 and Table 2. As shown in Fig. 7, the specific surface area of the micropores in D-CM mixed with $\mathrm{K}_{2} \mathrm{CO}_{3}$ was greater than that in the other blend conditions. The specific surface areas of the mesopores in D-CM $\mathrm{CaCO}_{3}$ char and mesopores and macropores in D-CM Na${ }_{2} \mathrm{CO}_{3}$ char were also greater than those in the other conditions. Statistical results of the pore structure test are shown in Table 2. Compared with raw CM, D-CM char had a larger specific surface area, pore volume, and smaller pore size. Compared with $\mathrm{CM}$ char, D-CM char mixed with $\mathrm{K}_{2} \mathrm{CO}_{3}, \mathrm{Na}_{2} \mathrm{CO}_{3}$, and $\mathrm{CaCO}_{3}$ showed larger specific surface area, pore volume, and pore size in different degrees. The specific surface area was in the order of $\mathrm{CaCO}_{3}>\mathrm{K}_{2} \mathrm{CO}_{3}>\mathrm{Na}_{2} \mathrm{CO}_{3}>\mathrm{MgCO}_{3}$. The D-CM MgCO $\mathrm{Mg}_{3}$ char had a smaller specific surface area and a larger pore volume and size than the other samples. Combined with the curve of characteristic combustion in Fig. $4 \mathrm{~b}$, the addition of $\mathrm{K}_{2} \mathrm{CO}_{3}, \mathrm{Na}_{2} \mathrm{CO}_{3}$, and $\mathrm{CaCO}_{3}$ in D-CM increased the specific surface area of char, which consequently improved the combustion characteristics. Moreover, the low pore structure of $\mathrm{D}-\mathrm{CM} \mathrm{MgCO}_{3}$ char was

Table 2 Pore structure of AAEM species blended with D-CM char

\begin{tabular}{|c|c|c|c|}
\hline Sample & $\begin{array}{l}\text { Specific surface } \\
\text { area }\left(\mathrm{m}^{2} \mathrm{~g}^{-1}\right)\end{array}$ & $\begin{array}{l}\text { Pore volume } \\
\left(\mathrm{cm}^{3} \mathrm{~g}^{-1}\right)\end{array}$ & Pore size $(\mathrm{nm})$ \\
\hline CM raw & 0.3276 & 0.0061 & 75.0179 \\
\hline D-CM char & 3.6274 & 0.0107 & 12.9783 \\
\hline D-CM K ${ }_{2} \mathrm{CO}_{3}$ char & 7.3350 & 0.0288 & 15.9371 \\
\hline D-CM Na ${ }_{2} \mathrm{CO}_{3}$ char & 6.6835 & 0.0489 & 29.2414 \\
\hline D-CM $\mathrm{CaCO}_{3}$ char & 8.0680 & 0.0246 & 13.0130 \\
\hline D-CM $\mathrm{MgCO}_{3}$ char & 3.0662 & 0.0272 & 36.0255 \\
\hline
\end{tabular}


further explained as a serious sinter and a decreasing porosity, which consequently declined reactivity.

\subsection{Characteristic temperature}

The effect of blend AAEM species on the combustion of CM was qualitatively analyzed. The combustion characteristic temperatures of the $\mathrm{K}_{2} \mathrm{CO}_{3}, \mathrm{Na}_{2} \mathrm{CO}_{3}, \mathrm{CaCO}_{3}$, and $\mathrm{MgCO}_{3}$ blends with different proportions in CM and D-CM are shown in Fig. 8. The various proportions of $\mathrm{CaCO}_{3}$ and $\mathrm{MgCO}_{3}$ blends increased $T_{\mathrm{ig}}$ and $T_{\max }$, and the $T_{\mathrm{ig}}$ and $T_{\max }$ increase levels of the $\mathrm{MgCO}_{3}$ blend in $\mathrm{CM} / \mathrm{D}-\mathrm{CM}$ were higher than those of the $\mathrm{CaCO}_{3}$ blend. Various blend proportions of $\mathrm{K}_{2} \mathrm{CO}_{3}$ and $\mathrm{Na}_{2} \mathrm{CO}_{3}$ reduced $T_{\mathrm{ig}}$ and $T_{\max }$, and the decrease range of $T_{\mathrm{ig}}$ and $T_{\max }$ was lower in the $\mathrm{K}_{2} \mathrm{CO}_{3}$ blend than in the $\mathrm{Na}_{2} \mathrm{CO}_{3}$ blend. This result indicates that the effect of the AAEM species on CM/D-CM was the same before reaching the reaction peak. The $T_{\mathrm{ig}}$ and $T_{\max }$ of D-CM were higher than those of CM, indicating that the internal AAEM species played a positive role in the initial reaction period.

$T_{\mathrm{b}}$ decreased as the addition amount of AAEM species was increased, but a different trend was observed between $\mathrm{CM}$ and D-CM. Except for blending $\mathrm{Na}_{2} \mathrm{CO}_{3}$ in $\mathrm{CM}$, the positive effect of mixing AAEM on $T_{\mathrm{b}}$ was enhanced as the amount of AAEM was increased. However, the $T_{\mathrm{b}}$ of D-CM initially decreased and then
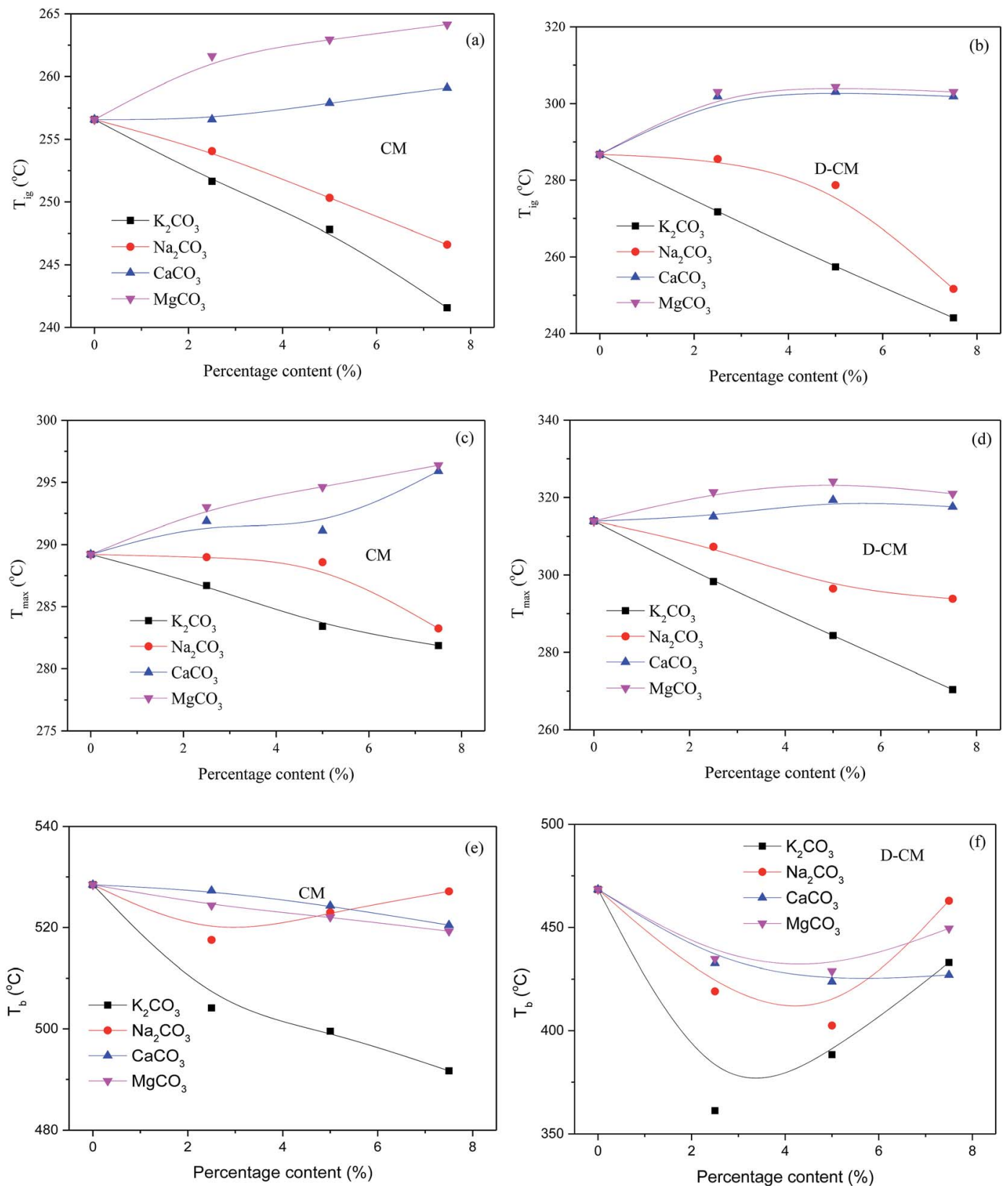

Fig. 8 Effect of AAEM amounts on the characteristic temperature of CM/D-CM combustion. (a) $T_{\text {ig, }}$ CM; (b) $T_{\text {ig, }} D-C M$; (c) $T_{\text {max }}$ CM; (d) $T_{\text {max }}$, D$C M$; (e) $T_{b}, C M$; (f) $T_{b}, D-C M$. 

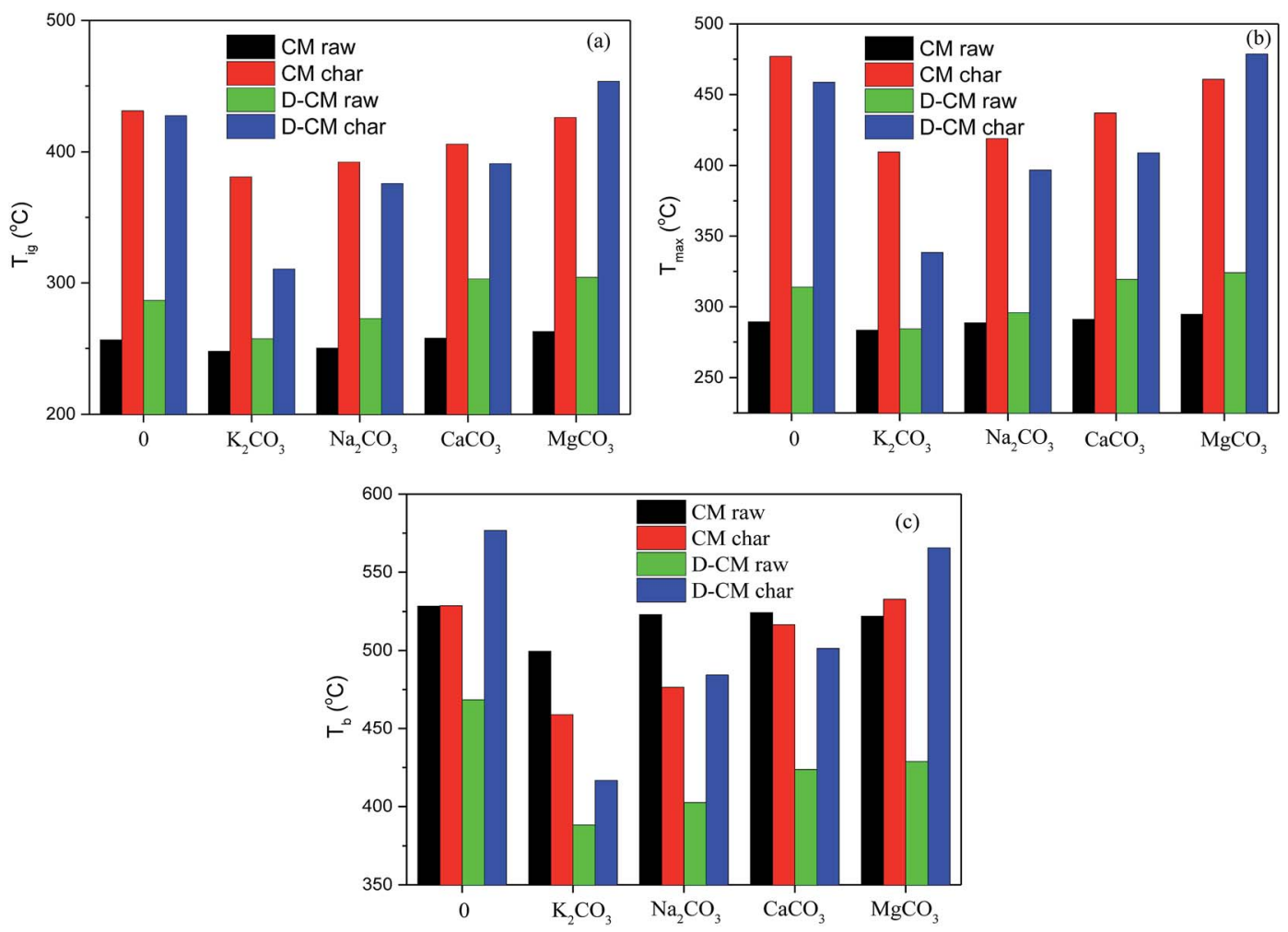

Fig. 9 Effect of AAEM species on the characteristics temperature of raw and char samples. (a) $T_{\text {ig, }}$ (b) $T_{\max }$ (c) $T_{\mathrm{b}}$.

further decreased as the amount of AAEM species was increased from $2.5 \%$ to $7.5 \%$. Meanwhile, the $T_{\mathrm{b}}$ of D-CM was lower than that of CM. Various amounts of AAEM species mixing with CM and D-CM indicates a competitive relationship, which plays a positive role in the reactivity and an inhibitory role in the contact between $\mathrm{C}$ and $\mathrm{O}_{2}$ at the core of $\mathrm{CM}$ particles during the burnout period. The amount of external AAEM species to be added needs to be controlled within $5 \%$. In conclusion, the effect of mixing AAEM in CM or D-CM follows $\mathrm{K}, \mathrm{Na}, \mathrm{Ca}$, and $\mathrm{Mg}$, gradually.

Volatile matter and char combustion occur during solid fuel combustion. The content of volatile matter in CM reached $45.80 \%$, whereas that of fixed carbon was only $12.52 \%$ (Table 1 ). In this case, the impact of AAEM species on volatile matter and char combustion was unclear. As shown in Fig. 9, the $T_{\text {ig }}$ and $T_{\max }$ of char were much higher than those of the raw sample, and the change rule of char after mixing $\mathrm{K}_{2} \mathrm{CO}_{3}, \mathrm{Na}_{2} \mathrm{CO}_{3}$, $\mathrm{CaCO}_{3}$, and $\mathrm{MgCO}_{3}$ was much higher than that of raw char. $T_{\mathrm{ig}}$, $T_{\max }$, and $T_{\mathrm{b}}$ increased after blending these substances in sequence, but a difference in the range was observed. The $T_{\mathrm{ig}}$ and $T_{\max }$ of CM partly reflect the reaction of volatile matter, especially for a high volatile matter content of CM. During the combustion of CM, the catalytic effect of AAEM species is unclear. However, the catalytic effect during the combustion of $\mathrm{CM}$ char without volatile matter content was obvious. For D-CM char, the catalytic effect of AAEM species was further reflected. In summary, the influence of $\mathrm{K}_{2} \mathrm{CO}_{3}, \mathrm{Na}_{2} \mathrm{CO}_{3}, \mathrm{CaCO}_{3}$, and $\mathrm{MgCO}_{3}$ on combustion was mainly reflected in char combustion, and the existence of volatile matter weakened the effect.

\section{Conclusion}

This study investigated the effects of AAEM species on the combustion characteristics of CM. K and Na in raw CM catalyzed the volatile release phase, and all of the AAEM species (K, $\mathrm{Na}, \mathrm{Ca}$, and $\mathrm{Mg}$ ) in raw $\mathrm{CM}$ catalyzed the burnout phase. With the external addition of AAEM to D-CM, $\mathrm{K}$ and $\mathrm{Na}$ exerted an obvious positive effect on combustion, and this effect changed with their addition amount. Meanwhile, the positive effect of $\mathrm{Ca}$ and $\mathrm{Mg}$ did not change with the addition amount. $\mathrm{K}, \mathrm{Na}$, and $\mathrm{Ca}$ demonstrated a positive effect on both CM char and D-CM char, but the effect on the latter was more significant than that on the former. $\mathrm{Mg}$ exhibited no obvious promotion effect on CM char and D-CM char. Analysis of D-CM char mixed with $5 \% \mathrm{~K}, \mathrm{Na}, \mathrm{Ca}$, and $\mathrm{Mg}$ revealed that the positive effect of $\mathrm{K}, \mathrm{Na}$, and $\mathrm{Ca}$ is related to the decrease in graphitization degree and the increase in specific surface area. Meanwhile, the negligible positive effect of $\mathrm{Mg}$ is related to the increase in graphitization degree and decrease in specific surface area.

\section{Conflicts of interest}

There are no conflicts to declare.

\section{Acknowledgements}

This research was financially supported by the Natural Science Foundation of Hubei Provincial (2017CFB231), the Special Fund for Agro-scientific Research in the Public Interest of China 
(201303091) and the Fundamental Research Funds for the Central Universities (2662015QD048 and 2015PY077).

\section{References}

1 D. Gao, T. Chen and B. Liu, Geographical Research, 2006, 25, 311-319.

2 C. Font-Palma, Energy Convers. Manage., 2012, 53, 92-98.

3 K. B. Cantrell, T. Ducey, K. S. Ro and P. G. Hunt, Bioresour. Technol., 2008, 99, 7941-7953.

4 M. Fatih Demirbas, M. Balat and H. Balat, Energy Convers. Manage., 2011, 52, 1815-1828.

5 L. Zhang, C. Xu and P. Champagne, Energy Convers. Manage., 2010, 51, 969-982.

6 X. Flotats, A. Bonmatí, B. Fernández and A. Magrí, Bioresour. Technol., 2009, 100, 5519-5526.

7 N. H. Florin, A. R. Maddocks, S. Wood and A. T. Harris, Waste Management, 2009, 29, 1399-1408.

8 Y. Xin, H. Cao, Q. Yuan and D. Wang, Waste Management, 2017, 68, 618-625.

9 X. Liu, Z. Li, Y. Zhang, R. Feng and I. B. Mahmood, Waste Management, 2014, 34, 1619-1626.

10 W.-T. Tsai, C.-N. Huang, H.-R. Chen and H.-Y. Cheng, Waste Biomass Valorization, 2015, 6, 975-981.

11 S.-Y. Zhang, R.-Y. Hong, J.-P. Cao and T. Takarada, Bioresour. Technol., 2009, 100, 4278-4283.

12 S. Xiu, H. K. Rojanala, A. Shahbazi, E. H. Fini and L. Wang, J. Therm. Anal. Calorim., 2012, 107, 823-829.

13 D. S. Pandey, M. Kwapinska, A. Gómez-Barea, A. Horvat, L. E. Fryda, L. P. L. M. Rabou, J. J. Leahy and W. Kwapinski, Energy Fuels, 2016, 30, 3085-3096.

14 W.-T. Tsai and S.-C. Liu, Biomass Convers. Biorefin., 2016, 6, 71-77.

15 K. Annamalai, B. Thien and J. Sweeten, Fuel, 2003, 82, 11831193.

16 S. Yurdakul, Renewable Energy, 2016, 89, 215-223.

17 X. Shen, G. Huang, Z. Yang and L. Han, Appl. Energy, 2015, 160, 108-119.

18 C.-Z. Li, Fuel, 2013, 112, 609-623.

19 D. Lv, M. Xu, X. Liu, Z. Zhan, Z. Li and H. Yao, Fuel Process. Technol., 2010, 91, 903-909.

20 T. P. Vispute, H. Zhang, A. Sanna, R. Xiao and G. W. Huber, Science, 2010, 330, 1222-1227.

21 H. Zhang, S. Shao, X. Rui, D. Shen and J. Zeng, Energy Fuels, 2014, 28, 52-57.

22 L. Jiang, S. Hu, L.-s. Sun, S. Su, K. Xu, L.-m. He and J. Xiang, Bioresour. Technol., 2013, 146, 254-260.

23 J. Cheng, F. Zhou, X. Xuan, J. Liu, J. Zhou and K. Cen, Fuel, 2017, 187, 398-402.

24 R. Jiménez, X. García, T. López and A. L. Gordon, Fuel Process. Technol., 2008, 89, 1160-1168.
25 L. Jiang, S. Hu, Y. Wang, S. Su, L. Sun, B. Xu, L. He and J. Xiang, Int. J. Hydrogen Energy, 2015, 40, 15460-15469.

26 S. Hu, L. Jiang, Y. Wang, S. Su, L. Sun, B. Xu, L. He and J. Xiang, Bioresour. Technol., 2015, 192, 23-30.

27 L. J. R. Nunes, J. C. O. Matias and J. P. S. Catalão, Renewable Sustainable Energy Rev., 2016, 53, 235-242.

28 D. Lynch, A. M. Henihan, W. Kwapinski, L. Zhang and J. J. Leahy, Energy Fuels, 2013, 27, 4684-4694.

29 P. Billen, J. Costa, L. van der Aa, L. Westdorp, J. Van Caneghem and C. Vandecasteele, Energy Fuels, 2014, 28, 5455-5462.

30 K. Wang, Z. Yin, P. Zhao, D. Han, X. Hu and G. Zhang, Energy Fuels, 2015, 29, 4428-4435.

31 V. Stanković, M. Gorgievski and D. Božić, Biomass Bioenergy, 2016, 88, 17-23.

32 H. Yang, R. Yan, H. Chen, D. H. Lee and C. Zheng, Fuel, 2007, 86, 1781-1788.

33 F. Zhang, M. Fan, X. Huang, M. D. Argyle, B. Zhang, B. Towler and Y. Zhang, Fuel Process. Technol., 2017, 161, 145-154.

34 A. Karimi and M. R. Gray, Fuel, 2011, 90, 120-125.

35 B. Feng, S. K. Bhatia and J. C. Barry, Carbon, 2002, 40, 481496.

36 X. Wu, J. Tang and J. Wang, Fuel, 2016, 165, 59-67.

37 B. Yi, L. Zhang, Z. Mao, F. Huang and C. Zheng, Fuel Process. Technol., 2014, 128, 17-27.

38 X. Gong, Z. Guo and Z. Wang, Combust. Flame, 2010, 157, 351-356.

39 E. Abbasi-Atibeh and A. Yozgatligil, Fuel, 2014, 115, 841-849. 40 B. Yi, L. Zhang, Q. Yuan, S. Yan and C. Zheng, Fuel Process. Technol., 2016, 152, 294-302.

41 M. V. Kok and E. Özgür, Fuel Process. Technol., 2013, 106, 739-743.

42 M. Otero, M. E. Sanchez, X. Gómez and A. Morán, Waste Management, 2010, 30, 1183-1187.

43 B. Yi, L. Zhang, F. Huang, Z. Xia, Z. Mao, J. Ding and C. Zheng, Energy Convers. Manage., 2015, 103, 439-447.

44 B. Yi, L. Zhang, F. Huang, Z. Mao and C. Zheng, Appl. Energy, 2014, 132, 349-357.

45 M. Baniasadi, A. Tugnoli, R. Conti, C. Torri, D. Fabbri and V. Cozzani, Renewable Energy, 2016, 90, 458-468.

46 A. Gani and I. Naruse, Renewable Energy, 2007, 32, 649-661. 47 Z. Zhou, X. Hu, Z. You, Z. Wang, J. Zhou and K. Cen, Thermochim. Acta, 2013, 553, 54-59.

48 L. Jiang, X. Yuan, H. Li, Z. Xiao, J. Liang, H. Wang, Z. Wu, X. Chen and G. Zeng, Energy Convers. Manage., 2015, 106, 282-289.

49 B. Feng, S. K. Bhatia and J. C. Barry, Energy Fuels, 2003, 17, 744-754.

50 C.-Z. Li, Fuel, 2007, 86, 1664-1683. 